\title{
ВИКОРИСТАННЯ СУЧАСНОГО ПРОГРАМНОГО ЗАБЕЗПЕЧЕННЯ В СИСТЕМАТИЗАЦІЇ ЛІТЕРАТУРНИХ ДАНИХ ЗА ІНТРАНАЗАЛЬНИМИ ЛІКАРСЬКИМИ ЗАСОБАМИ
}

\author{
๑Б. С. Бурлака

\section{Запорізький державний медичний університет}

\begin{abstract}
Резюме: стаття присвячена оптимізації пошуку літературних даних із розробки, технології виготовлення та стандартизації лікарських засобів інтраназального введення шляхом використання сучасного програмного забезпечення. Для цього доцільно використовувати такі програмні засоби, як Mendeley® aбо Zotero@.
\end{abstract}

Ключові слова: інтраназальні лікарські форми, пошук інформації через мережу internet.

Вступ. Одним з етапів створення нових лікарських засобів є узагальнення та систематизація існуючих інформаційних потоків у вигляді наукових тез, статей, патентів, авторефератів, дисертацій, монографій. Часто такий процес для дослідників є досить кропітким та трудомістким, при цьому спеціаліст повинен володіти спеціальними навичками з пошуку публікацій як іноземного, так і вітчизняного походження. Необхідно зазначити, що пошук ускладняє також значне різноманіття форматів вихідних даних, які можуть змінюватися залежно від пошукової системи, типу бази даних, характеру видавництва журналу [1, 2].

Після систематизації публікацій із проблеми, опрацювання отриманої інформації та оприлюдненні результатів власних експериментальних досліджень необхідно враховувати вимоги до оформлення літературних даних. Причому залежно від типу публікації, видавництва журналу, вимог нормативних документів (державних стандартів) правила цитування та оформлення списків літератури можуть значно відрізнятись.

Наукова інформація із інтраназальних лікарських засобів для місцевого та системного застосування розповсюджена в різноманітних базах даних та бібліотеках, деякі фрагменти їі опубліковані в наукових журналах на багатьох мовах у вигляді тез, статей, коротких повідомлень та патентів. Систематизація та опрацювання такої різнопланової інформації у дослідників викликає певні ускладнення.

Мета роботи. Провести аналіз сучасного програмного забезпечення, яке може бути використане для систематизації літературних даних із інтраназальних лікарських засобів.

Методи дослідження. Як матеріал використовували доступне програмне забезпечення, яке використовують для систематизації на- укових досліджень. Інформацією слугували тези, статті, патенти, автореферати та дисертації із назальних лікарських засобів. В отриманого програмного забезпечення аналізували функціональні можливості з урахуванням зручності, інтуїтивності та доступності.

Результати й обговорення. На початковому етапі проводили літературний пошук із інтраназальних лікарських засобів дистанційно через мережу internet у таких відомих базах даних, як Національна Медична Бібліотека США (http:// www.ncbi.nlm.nih.gov/pubmed/), повнотекстовій базі даних ScienceDirect (http:// www.sciencedirect.com/), повнотекстовій базі даних Springerlink (http://www.SpringerLink.com), спеціалізованій БД "Винаходи (корисні моделі) в Україні” (http://sips.gov.ua), спеціалізованій БД «Российских патентных документов» (http:// www1.fips.ru/), науковій електронній бібліотеці eLIBRARY.RU (http://elibrary.ru), Національній бібліотеці України імені В. І. Вернадського (http:/ /www.nbuv.gov.ua/). В результаті пошуку були знайдені літературні посилання з режимом повного доступу до відбитків публікацій та без нього.

Як програмне забезпечення для роботи 3 бібліографічною інформацією досліджували такі засоби, як EndNote $\odot$, Reference Manager®, ProCite $\odot$, Библио-Мастер®), Mendeley®, Zotero®. Відомо, що ці програми можуть автоматизувати деякі функції із управління науково-пошукової інформації та бути застосовані однією людиною або групою людей [6]. Їхні функціональні характеристики мають схожий характер і характеризуються можливістю ведення електронної бази публікацій як в ручному режимі, так і автоматичному шляхом імпорту цифрового ідентифікатора об'єкта (digital object identifier - DOI), міжнародного стандартного книжкового номеру (International Standard Book Number - ISBN),

ISSN 2312-0967. Pharmaceutical review. 2015. № 1 
Інформаційні та інноваційні технології у фармації Informational and innovational technologies in pharmacy ідентифікатора документа в системі Pubmed (PMID) таких форматів, як BibTex, RIS та інших. Необхідно зазначити, що переховані програмні засоби мають можливість зберігати не тільки бібліографічну інформацію, а й пов'язані з нею повні тексти публікацій.

Протестувавши можливості перерахованих вище програмних засобів, ми зупинилися на Mendeley () i Zotero@), які мають схожий інтерфейс, функціонал та можуть вільно обмінюватись інформацією шляхом експорту її в універсальні формати RIS або BibTeX. Такі програми можуть застосовуватись в середовищах Windows $($, Linux $($, Mac OS $\odot$, є безкоштовними та зручними для використання. Однією з переваг таких засобів є можливість синхронізації створеної локальної бази літературних переліків та їх повних текстів із вибраної проблеми з зовнішніми серверами, які розташовані в мережі internet, що, в свою чергу, захищає від несподіваної втрати накопиченої інформації та надає можливість отримати доступ до своєї інформації з будь-якого місця. Для цього в Mendeley® та Zotero(c) можна використовувати безкоштовні акаунти, які мають певний об'єм дискового простору, при вичерпанні якого його можна отримати за додаткову оплату. B Zotero@ поряд з цим $€$ можливість використовувати власні або безкоштовні сервера, які працюють за протоколом WebDAV(наприклад, «яндекс.Диск»), що дозволяє безкоштовно зберігати повні тексти публікацій з власної бібліотеки в мережі internet.

Mendeley@ та Zotero@ дозволяють не тільки обмінюватися бібліографією та файлами повних текстів між користувачами, а й одночасно працювати багатьом користувачам 3 знайденою інформацією. Такий підхід значно полегшує наповнення літературної бази по конкретній проблемі. Так, нами для оптимізації пошуку, узагальнення та обробки інформації з інтраназальних лікарських засобів використовувався багатокористувацький підхід, в якому кожний з користувачів відповідав за свою ланку роботи. Це дозволило ефективно оброблювати великі масиви інформації.

Імпортування знайденої інформації за інтраназальними лікарськими формами здійснювали шляхом введення ідентифікатора DOI в полі пошуку головного меню програми. При цьому відбувається пошук метаданих із даного ідентифікатора через мережу інтернет та запис до програми таких характеристик, як автор публікації, назва публікації, видавництво, рік, випуск, сторінки та інше. Для прискорення пошуку та запису інформації до локальної бази знань із інтраназальних лікарських форм вносили набори ідентифікаторів DOI. Система аналізувала такий набір ідентифікаторів і після завершення збору інформації пропонувала здійснити вибір серед знайдених посилань для подальшого запису до бази знань. Повні тексти публікацій у більшості випадків завантажували окремо та прикріплювали до імпортованої раніше бібліографії.

Необхідно зазначити, що в програмному засобі Zotero $\odot$ є можливість пошуку метаданих в повнотекстових документах. Для використання цієї функції знайдені раніше публікації у форматі Portable Document Format (pdf) та Rich Text Format (RTF) розташовували в одній папці і в налаштуваннях програми вказували адресу цієї папки. Відбувається створення бібліографічної карточки інформації з вихідного файлу та прикріплення його до новоствореної карточки.

У деяких випадках ми використовували прямий імпорт метаінформації з відкритої сторінки публікації в браузері Mozilla Firefox. Для цього спочатку встановили компонент Zotero@ до браузеру та потім застосовували піктограму «Создать новый документ с текущей страницы». За необхідності створювали нотатки з відкритої сторінки публікації в браузері шляхом виділення необхідних абзаців текстів та вибору меню програми «Создать документ и заметку Zotero из выделенного».

Паралельно з зберіганням інформації з інтраназальних лікарських засобів ми додатково додавали до кожного посилання характеристику інформації у вигляді тегів. Створена система тегів дозволяє швидко фільтрувати накопиченні знання із інтраназальних лікарських засобів, незважаючи на те, в якій категорії вони знаходяться. Тобто, наприклад, при виборі тегу «реологічні дослідження» в Zotero ( ) відбувається пошук по всій бібліотеці тез, статей, патентів та інших публікацій - це дозволяє користувачеві оптимізувати час пошуку і не проглядати всі публікації по кожній категорії.

Для пошуку інформації в створеній бібліотеці з інтраназальних лікарських засобів ми користувались категоріями та тегами, а також пошуковою системою програми. Пошуковий механізм дозволяє знаходити інформацію не тільки в вихідних даних публікацій, а й в повних текстах документів прикріплених до бібліотечних карток. При чому розробниками в інтерфейсі програми реалізована система сортування 3 будь-якого 3 полів вихідних даних, наприклад, таких, як назва журналу, видавництво, рік публікації та інших.

У програмному засобі Zotero® надана можливість працювати одночасно з декількома створеними бібліотеками або базами знань 3 конкретної проблеми. Для використання цієї функції достатньо в налаштуваннях програми

ISSN 2312-0967. Фармацевтичний часопис. 2015. № 1 
Інформаційні та інноваційні технології у фармації Informational and innovational technologies in pharmacy

вказати шлях до іншої бібліотеки на диску відразу в інтерфейсі програми ці дані відобразяться.

Широкі можливості програмного засобу Zotero( ) в роботі з метаданими збережених об'єктів в базі надають значні перспективи щодо детального та глибокого аналізу інформації. Для цього в програмі Zotero@) передбачена можливість підключення додаткових плагінів, які можуть суттєво розширювати базовий функціонал програми. Наприклад, завдяки плагіну «Zotero Scholar Citations» користувач зможе здійснити онлайн пошук індексу цитувань публікацій через сервіс Google Scholar та відобразити результат своєї роботи в інтерфейсі програми. Для створення інтелект-карт або ж карт пам'яті (mind map) на основі внесених даних доцільно використовувати плагін «Visual Understanding Environment», який дозволяє візуалізувати створену бібліотеку та аналізувати тенденції розвитку наукових досліджень з заданої проблеми. Крім того, цей плагін додатково дозволяє працювати декільком користувачам з отриманими картами пам'яті, що дозволяє групі дослідників одночасно працювати над проблемою. Для створених карт можна додатково створювати текстові пояснення, а також демонструвати їх у вигляді слайд-шоу, яке дозволяє візуалізувати на карті логіку представленої інформації.

Завдяки тісній інтеграції Mendeley® та Zotero@ 3 текстовим процесором Microsoft Word(C та іншими програмами при оформленні наукової публікації надана можливість зручно цитувати факти 3 літературних джерел шляхом вибору їх з бази, а також формувати в автоматичному режимі списки використаної літератури. Оформлення списку літератури можна швидко змінювати за рахунок вбудованих шаблонів або стилів (Citation Style Language), які є для багатьох журналів та видавництв. На даний момент нами проводиться адаптація стилю оформлення літературних списків відповідно до вимог ДСТУ гОСТ 7.1:2006.

Отримані колекції бібліографічних посилань щодо наукових досліджень в області інтраназальних лікарських засобів в Zotero( вували у персональному розділі «Моя бібліотека» і сортували відповідно категорій:

1) інтраназальні лікарські засоби місцевої дії;

2) інтраназальні лікарські засоби системної дії;

3) технологічні аспекти інтраназальних лікарських засобів;

4) доклінічні дослідження інтраназальних лікарських засобів;

5) клінічні дослідження інтраназальних лікарських засобів.
Така структура категорій дозволяє ефективно проводити первинний етап сортування інформації та значно економить час дослідників на ії опрацювання.

Створені категорії бібліографічних посилань з інтраназальних лікарських засобів у персональному розділі «Моя бібліотека» дозволили виявити наступне. Інтраназальне введення лікарських засобів для місцевого застосування відоме і застосовується досить давно з метою отримання протизапального, протиалергічного, судинозвужуючого, очищувального ефекту.

Останніми десятиліттями вчені отримали позитивні результати щодо використання інтраназального шляху введення лікарських засобів для системного застосування. Біодоступність системних інтраназальних препаратів різної фармакологічної дії виявилася вищою порівняно $з$ пероральним застосуванням, часто-густо $€$ такою, як і при парентеральному введенні. При інтраназальному шляху введення діючі речовини потрапляють відразу в загальний кровообіг і на відміну від ентерального шляху, минують пресистемну елімінацію, що, в свою чергу, попереджає передчасне руйнування препарату. Характеризуючи властивості та характер інтраназального шляху введення лікарських засобів, перспективним $€$ розробка інтраназальних терапевтичних систем для лікування церебральних патологій. Такий спосіб введення діючих речовин забезпечуватиме прямий транспорт препарату з носової порожнини до центральної нервової системи.

3 технологічної точки зору, при створенні нових інтраназальних препаратів потрібно забезпечити не тільки ефективну доставку лікарського засобу в порожнину носа, але й не впливати на фізіологічну функцію дихальної системи.

Аналізуючи отриману інформацію з інтраназальних форм нами було встановлено, що найбільш часто застосовують форми випуску препаратів у вигляді водних розчинів як найбільш зручні і практичні при різних типах введення, наприклад, таких, як спреї або краплі. Поряд 3 цим, коли діючі речовини легко руйнуються та $є$ нестабільними в водному середовищі, можуть застосовуватися інтраназальні порошки, які мають певні переваги та характеризуються відсутністю консервантів і стабільністю при зберіганні. Назальні гелі, емульсії та суспензії, завдяки свої природі, довше знаходяться в носовій порожнині, порівняно з водними розчинами, а також мають менш виражену подразнюючу активність слизової оболонки носа. Проте серед особливостей застосування таких форм випуску необхідно відзначити складність дозування препарату.

ISSN 2312-0967. Pharmaceutical review. 2015. № 1 
Інформаційні та інноваційні технології у фармації

Informational and innovational technologies in pharmacy

Як допоміжні речовини в інтраназальних лікарських формах застосовуються консерванти, зволожуючі речовини, такі, як гліцерин або пропіленгліколь, буферні розчини для підтримання заданого значення $\mathrm{pH}$ середовища, компоненти, які підвищують назальне всмоктування, антиоксиданти та інші інгредієнти.

\section{Література}

1. Web in Learning. Как оформить список литературы для зарубежного журнала [Електронний ресурс] / Режим доступу: http://web-in-learning.blogspot.com/ 2012/12/blog-post.html. - Загл. з титул. екрану (прогл. 20 листопада 2014 року).

2. Требования к содержанию и оформлению рукописей научных статей : научн.-практ. журнал «Экономика промышленности» / осн. НАН Украины Институт экономики промышленности. - Донецк, 2012. C. 14-17.

3. Bitter C. Nasal Drug Delivery in Humans / C. Bitter, K. Suter-Zimmermann, C. Surbera //Current Problems in Dermatology. - KARGER. - 2011. - Vol. 40. - P. 20-35. 4. Illum L. Nasal drug delivery - Recent developments
Висновки. 1. У результаті досліджень, був проведений пошук літературних даних із розробки, технології виготовлення та стандартизації лікарських засобів інтраназального введення.

2. Встановлено, що для оптимізації зберігання, аналізу та обробки літературних даних доцільно використовувати сучасне програмне забезпечення.

and future prospects / L. Illum // Journal of Controlled Release. - 2012 - Vol. 161, № 2. - P. 254-263.

5. Pires A. Intranasal drug delivery: how, why and what for? / A. Pires, A. Fortuna, G. Alves // J. Pharm. Sci. 2009. - Vol. 12, № 3. - P. 288-311.

6. Веб-сайт Ассоциации LRC [Электронний ресурс] / [Автори асоціації]. Программы для работы с библиографической информацией. - Електрон. дан. - Режим доступу : http://Ircnetwork.org/tt8r.- Загл. з титул. екрану (прогл. 20 листопада 2014 року).

7. Qian S. Development, characterization and application of in situ gel systems for intranasal delivery of tacrine / S. Qian, Y. C. Wong, Z. Zuo // Int. J. Pharm. - 2014. Vol. 468, № 1-2. - P. 272-282.

\section{ИСПОЛЬЗОВАНИЕ СОВРЕМЕННОГО ПРОГРАММНОГО ОБЕСПЕЧЕНИЯ ДЛЯ СИСТЕМАТИЗАЦИИ ЛИТЕРАТУРНЫХ ДАННЫХ ПО ИНТРАНАЗАЛЬНЫМ ЛЕКАРСТВЕННЫМ СРЕДСТВАМ}

\section{Б. С. Бурлака}

\section{Запорожский государственный медицинский университет}

Резюме: статья посвящена оптимизации поиска литературных данных по разработке, технологии изготовления и стандартизации лекарственных средств интраназального введения путем использования современного программного обеспечения. Отмечается, что для этого целесообразно использовать такие программные средства, как Mendeley๔ или Zotero®.

Ключевые слова: интраназальные лекарственные формы, поиск и информации через internet.

\section{USE OF MODERN SOFTWARE FOR SYSTEMATIZATION OF THE LITERATURE DATA FOR INTRANASAL DRUGS}

\section{B. S. Burlaka}

\section{Zaporizhzhia State Medical University}

Summary: the article is devoted to optimize search data in the literature on the development, manufacturing technology and standardization of drugs intranasal administration by using modern software. It is noted that for this purpose it is advisable to use such software as Mendeley@, or Zotero@.

Key words: intranasal, dosage forms, seach information on the internet.

Отримано 17.03.2015

ISSN 2312-0967. Фармацевтичний часопис. 2015. № 1 